\title{
Seasonal Fishery Closure in the Northern Bay of Bengal Causes Immediate but Contrasting Ecological and Socioeconomic Impacts
}

\author{
Mohammad Mahmudul Islam ${ }^{1 *}$, Amany Begum¹, Syed Mohammad Aminur Rahman ${ }^{2}$ \\ and Hadayet Ullah ${ }^{3}$
}

1 Department of Coastal and Marine Fisheries, Sylhet Agricultural University, Sylhet, Bangladesh, ${ }^{2}$ Department of Geography, Environment and Population, The University of Adelaide, Adelaide, SA, Australia, ${ }^{3}$ WorldFish, Bangladesh and South Asia

Office, Dhaka, Bangladesh

OPEN ACCESS

Edited by:

Alistair James Hobday,

Commonwealth Scientific

and Industrial Research Organisation

(CSIRO), Australia

Reviewed by:

Donna Marie Bilkovic,

Virginia Institute of Marine Science,

College of William \& Mary,

United States

Edward Jeremy Hind-Ozan, Department for Environment, Food and Rural Affairs, United Kingdom

*Correspondence:

Mohammad Mahmudul Islam

mahmud.cmf@sau.ac.bd

Specialty section:

This article was submitted to Marine Conservation

and Sustainability,

a section of the journal

Frontiers in Marine Science

Received: 01 May 2021

Accepted: 12 August 2021

Published: 24 September 2021

Citation:

Islam MM, Begum A,

Rahman SMA and Ullah H (2021)

Seasonal Fishery Closure in the Northern Bay of Bengal Causes Immediate but Contrasting Ecological

and Socioeconomic Impacts.

Front. Mar. Sci. 8:704056.

doi: 10.3389/fmars.2021.704056
Bangladesh has introduced a monsoonal fishery closure in the Bay of Bengal to ensure the conservation of fish stocks and productive breeding grounds. While the fishing ban has likely supported this goal, it has also sparked protest and resentment among small-scale fishers. This study investigated fishers' perceptions of the 65day fishing ban between May and July in the Bay of Bengal. We collected both qualitative and quantitative data from five coastal fishing communities. Data were analyzed to explore fishers' perceptions of the socioeconomic and ecological impacts of the closure. While most respondents agreed that the closure produced positive ecological outcomes, they felt that their income and food security had been negatively affected. Importantly, crew members perceived their losses to be more extreme than the boat skipper or owner due to their overreliance on the fishery and lack of alternative skills and occupations. These fishers cannot forfeit their livelihoods and food security needs, as they are already living on the margins of subsistence. This social ramification emphasizes the necessity of understanding the interconnection between fishers' socioeconomic conditions and conservation needs. Social-ecological trade-offs and inequalities raise the question of social equity and environmental justice, which could ultimately compromise management and conservation effectiveness and legitimacy. The involvement of local communities in the decision-making process for future fishery interventions could enhance both the livelihood opportunities and the positive ecological outcomes in the Bay of Bengal marine ecosystem.

Keywords: Bay of Bengal, fishing ban, small-scale fisheries, impact evaluation, Bangladesh

\section{INTRODUCTION}

Policymakers and managers consider seasonal fishery closure a useful intervention in addressing overexploitation and protecting species during their spawning season (Cinner et al., 2006; Arendse et al., 2007; Bavinck et al., 2008; Cohen et al., 2013; Colwell et al., 2019). Many different seasonal fishing closures have been implemented worldwide, such as restrictions on trawling by motorized and mechanized vessels (Morton, 2011; Barley Kincaid and Rose, 2014; Loring, 2017), shrimp 
trawling (Vivekanandan et al., 2010), and gill netting (Loring, 2017) for a short and defined period of time or permanently (Bavinck et al., 2008; Morton, 2011; Pranovi et al., 2015; Colwell et al., 2019; Amali Infantina et al., 2020) or for a single species (Vivekanandan et al., 2010; Oliver et al., 2015). These are widely recognized conservation and management measures that promote the safeguarding of species by restraining fishing and shielding the species during their spawning season (Hargraves, 2011; Cohen et al., 2013; Chimba and Musuka, 2014; MusielloFernandes et al., 2017; Narayanakumar et al., 2017). Seasonal fishing closures have also become an indispensable tool in the worldwide mission of improving governance and advancing fishery sustainability (Kooiman et al., 2005; Central Marine Fisheries Research Institute [CMFRI], 2007). This management intervention also offers ecological restoration of the resources of depleted fisheries and eventual economic benefits to dependent communities (Rahman et al., 2011; Islam et al., 2018; van Brakel et al., 2018).

Seasonal fishery closures are likely to yield various ecological outcomes, such as boosting fishers' catches (Cohen et al., 2013; Rola et al., 2018) and reduction in fuel use and associated reduction in $\mathrm{CO}_{2}$ emission, with reduced impacts upon ocean biodiversity (Narayanakumar et al., 2017). Such initiatives are considered robust regulatory measures expected to augment marine fisheries production as the stocks are allowed to spawn and grow (Narayanakumar et al., 2017; Napata et al., 2020). Closure for spawning will also positively effect population growth, as well as reducing annual fishing mortality by reducing fishing effort during and even after the closure (Arendse et al., 2007; Clarke et al., 2015). The biomass would be reasonably expected to increase due to the ban period, as it would otherwise have been exploited by the fishery as small-sized juveniles (Arendse et al., 2007; McClanahan, 2010; Napata et al., 2020). For example, in Australia, the seasonal trawling ban has yielded a substantial increase in fisheries production (Shyam et al., 2010). Similar results are evidenced for hilsa shad fisheries, where production increased following ban periods in Bangladesh (Rahman et al., 2014; Islam et al., 2018; Fisheries Resource Survey System [FRSS], 2019).

This conservation measure is known to cause serious socioeconomic disturbances (Finkbeiner et al., 2017; Brillo et al., 2019). Restriction on fishing has strong short-term negative impacts, particularly on the income and livelihood of vulnerable coastal fishers and their communities (Brillo et al., 2019; Napata et al., 2020), as there are no alternative employment opportunities during the fishing ban. This suggests that fishers are left with no other choice but to take on the full impact of the income loss caused by the ban (Aswathy et al., 2011; Brillo et al., 2019; Amali Infantina et al., 2020). This conservation regime generates unemployment and poverty (Shyam et al., 2010), leaving artisanal small-scale fishers and the crews of industrial fishers as the primary victims of the ban (Colwell and Axelrod, 2017). Loss of employment and income following such bans causes severe negative impacts upon livelihoods, and this generates anger, deprivation and distrust among fishers in the long term (Momtaz and Gladstone, 2008). The decrease in employment opportunities and lost income affect fishers and their families physiologically, alongside severe symptoms of depression, mental stress, and health hazards (Allen and Gough, 2006; Islam et al., 2016). A lack of domestic fish supply during the ban, followed by malnutrition, especially among women and children, was also observed in coastal areas (Islam et al., 2016). There are, however, long-term socioeconomic beneficial effects, as the fishery closures increase the future catch of valuable fish and thus increased per person profits (Bavinck et al., 2008; Cohen et al., 2013; Rola et al., 2018; Carvalho et al., 2019). There is also the prospect of an increased employment rate after the fishing ban ends (Brillo et al., 2019).

Although fishing bans represent a good prospect for the longterm sustainability of local fisheries, this conservation measure entails socioeconomic costs, particularly for laborers' livelihoods and well-being, which compromise the benefits of this strategy (Brillo et al., 2019). Small-scale fishers ultimately cope with this adverse situation by putting more pressure on the common pool fishery resources, and this is underpinned by socioeconomic implications. However, fishers' non-compliance with fishing rules and regulations to support their livelihood results in increasing pressure on fishery resources, use of destructive fishing gear and methods and a tendency to fish whatever is available, including larvae and juveniles (Murshed-e-Jahan et al., 2014). Regulations may be breached by fishers driven by various socioeconomic and political dynamics. Major drivers behind non-compliance with fishing regulations include lax enforcement, strong ties between violators and the local political establishment, bribery of enforcing authorities, poverty, indebtedness to moneylenders, insufficient incentives and lack of alternative livelihood options, all of which may force marginal fishers to continue fishing during the ban (Islam et al., 2018; Brillo et al., 2019; Napata et al., 2020). These activities cause severe damage to coastal fishery resources and create conflict between fishers and other resource users (Hussain and Hoq, 2010): there is a dilemma between conservation and livelihood sustainability.

Enhanced conservation management strategies in fisheries can help to alleviate economic and food insecurity (Sherman et al., 2018). However, the lack of community support is a significant obstacle in achieving the desired success for this management practice (Kincaid and Rose, 2014). Compliance with ban regulations is necessary for conservation, but this is strongly subject to the cooperation between the government and the local fishers (Bavinck et al., 2008). Compliance with the regulation restricting access is driven by the available alternative livelihood options and greater income security (Peterson and Stead, 2011; Catedrilla et al., 2012; Arias et al., 2015; Islam et al., 2017). Notably, stakeholders' involvement in fishery management can offer several advantages, including improved planning, conflict management and greater readiness to accept management decisions (Pita et al., 2010; Sampedro et al., 2017; Lorenzen and Camp, 2019).

Bangladesh has a recent history of spatial and temporal fishing bans for the conservation of fishery resources. For the protection and conservation of hilsa shad (Tenualosa ilisha) fisheries, the government of Bangladesh (GoB) has declared six sanctuaries in the Meghna-Padma and Andharmanik rivers, their tributaries and associated coastal waters. The GoB declared four riverine areas as hilsa sanctuaries in 2005, adding a fifth in 2011 and 
a sixth in 2018. A 2-month fishing ban has been imposed in these sanctuaries to protect jatka (juvenile hilsa less than $25 \mathrm{~cm}$ in size). Also, to facilitate breeding, there is a countrywide prohibition on catching brood hilsa for 22 days in October during the peak breeding season. There is also an 8-month countrywide ban from November to June every year on catching, carrying and selling jatka imposed by the Department of Fisheries (DoF) in collaboration with law enforcement agencies and local governments. In 2015, a 65-day fishing ban was first imposed on large commercial trawlers from 20 May to 23 July in the Bay of Bengal to facilitate increased fish breeding. In the same year, the legality of the ban was challenged in the High Court through a writ petition by the Marine Fisheries Association; however, the High Court upheld the government order.

In 2019, the ban was extended to all fishing vessels, including small-scale artisanal fishing boats. The ban came as an immediate shock and immense disappointment for most of the small-scale fishing communities, as they solely depend on fishing for their daily subsistence. The decision triggered unprecedented protests and demonstrations throughout the coastal region. Many smallscale fishers took to the street to protest against the sudden decision taken by the GoB to include small-scale coastal fisheries under the ban. These responses received wide coverage in both national and international news and social media. The fishers complained that the fishing ban drove them suddenly out of their fishing activities and placed their livelihoods in peril. The immediate effects of the ban were headlined in the New York Times as "Bangladesh's Fishing Ban Leaves Coastal Towns in 'Nightmare Situation”' (22 May 2019). Fishers' organizations demanded authorities either exempt artisanal fishers from the ban or provide adequate support for its duration. In response to this, the GoB decided to provide rice support to the affected poor and vulnerable fisher households under the government's Vulnerable Group Feeding (VGF) program. However, the fishers reminded the authorities that rice alone (i.e., single food subsistence) is not sufficient to sustain their families.

Although the 65-day fishing ban created widespread impacts on and uproar in coastal fishing communities, there is no systematic study to assess stakeholders' perceptions, including fishers', toward the socio-ecological effectiveness of the ban. There is therefore a need to examine the impact of the ban on coastal fishers, both their perceptions of the ecological effectiveness and their response to the negative effects of not fishing. This study thus specifically explores the stakeholders' (i.e., fishers') views on the socioeconomic implications and ecological effectiveness of the fishery closure and seek ways to improve fishers' compliance with the ban through effective management by exploring the drivers of compliance to the ban. It also presents the results in terms of key issues, problems of management as perceived of the fishers and how they responded to crises during the ban period.

\section{MATERIALS AND METHODS}

Five study sites in three coastal districts - the Patharghata area of Barguna district, the Mohipur and Kuakata areas of Patuakhali district, and the North Nuniarchora and Fishery Ghat areas of Cox's Bazar district - were selected for this study owing to their significant contribution to marine fisheries production in Bangladesh (Figure 1). Most coastal inhabitants in the study sites are entirely dependent on fishery resources for their livelihoods, either directly or indirectly.

Because the study targets a specific professional group, purposive sampling was employed to select individuals to

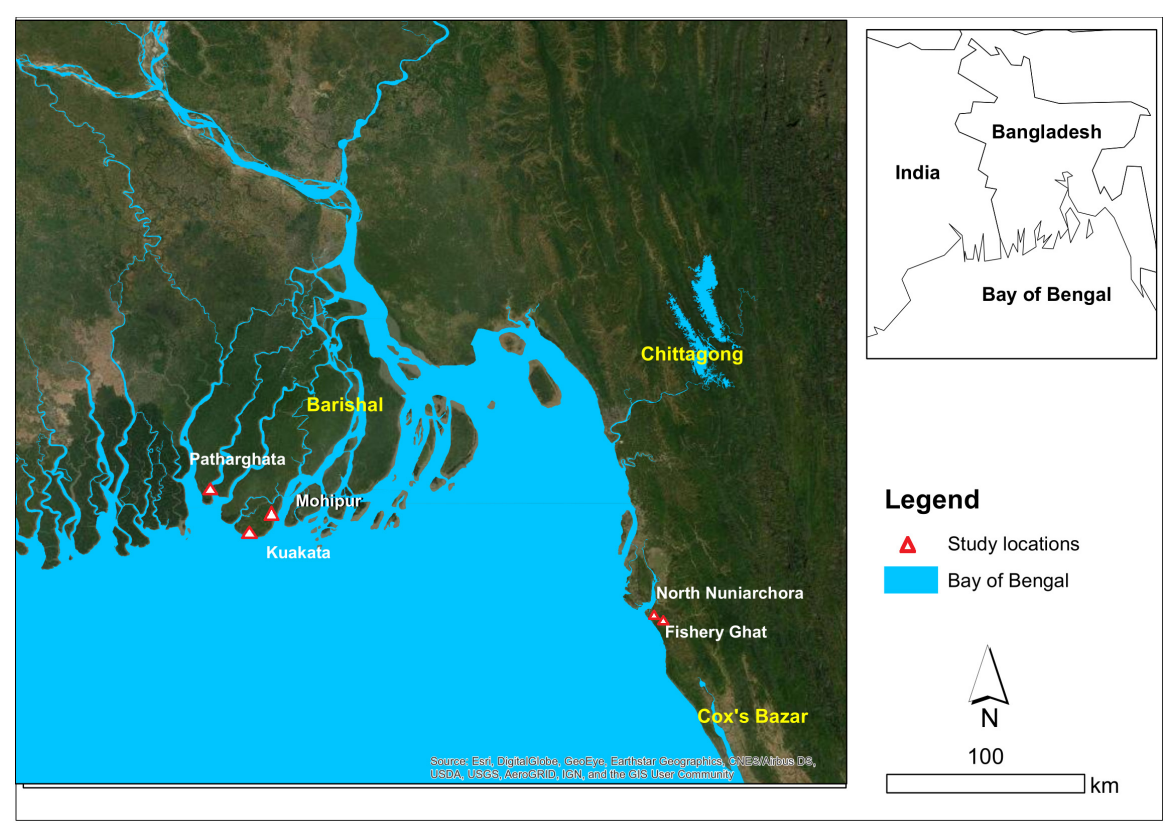

FIGURE 1 | Location of the study sites. 
interview to ensure that they were knowledgeable, seagoing fishers, because such respondents could provide the most relevant and rich data (Yin, 2015). Only purposive sampling can provide important information from particular, deliberately selected settings, persons or events (Maxwell, 1997). To gather data for the study, 150 fishers were interviewed from July to December 2019. Face-to-face interviews were conducted with fishers from three coastal districts: Barguna $(N=56)$, Patuakhali $(N=44)$, and Cox's Bazar $(N=50$; see Table 1). Both qualitative and quantitative methods were adopted for data collection. Interviews were performed informally by a semi-structured questionnaire that constituted both open-ended (qualitative) and close-ended (quantitative) questions (see Supplementary Material). The questionnaires aimed to collect information about the respondent's demographic characteristics (age, education, income, etc.); details of their fishing activity (target species and fishing methods, types of gears in use, and membership of any organization); fishing experience; level of dependence on fisheries; and their perceptions and attitudes toward fishery closures concerning ecological and socioeconomic impacts, their coping strategies and perceptions to improve management.

The interviews were conducted at fish landing sites, fisher households and local fish markets and shops, where fishermen spend their time engaged in various activities such as loading and unloading fish, mending nets, repairing gears and boats and even gossiping; these sites were selected to allow the fishers' views to be reflected without disturbance. An additional six focus group discussions (FGDs) were conducted, in which each group consisted of five to eight persons and took approximately $1 \mathrm{~h}$. The FGDs were done to extract qualitative information on the positive and negative consequences of the seasonal fishery closures in terms of socioeconomic and ecological performance. The participants of the individual interviews and FGDs were full time seagoing fishers (both crews and skippers). Another 20 key informant interviews were conducted with knowledgeable personnel such as fishery officers, NGO workers and office holders in fishers' organizations. Key informant interviewees were expected to answer questions based on their knowledge and experience, and this helped to validate and cross-check the information collected in the individual interviews.

Using descriptive statistics (e.g., frequencies and percentage), the socioeconomic profile of the respondents was analyzed. We used Welch's $t$-test to determine whether there was a significant

TABLE 1 | Number of respondents surveyed during the fisher survey among the study sites.

\begin{tabular}{llll}
\hline SI. no & Study site & District & $\begin{array}{l}\text { Number of } \\
\text { respondents } \\
\text { (n) }\end{array}$ \\
\hline 1 & Patharghata & Barguna & 56 \\
2 & Mohipur & Patuakhali & 29 \\
3 & Kuakata & Patuakhali & 15 \\
4 & North & Cox's Bazar & 33 \\
& Nuniarchora & & 17 \\
5 & Fishery Ghat & Cox's Bazar & Total $=150$
\end{tabular}

difference in income between the crew and boat skipper. We chose Welch's $t$-test because it performs better than Student's $t$-test whenever sample sizes and variances are unequal between groups (Delacre et al., 2017). Linear models were created using R 4.0.2 (R Core Team, 2020) to examine the factors (predictors) that most influence fishers' (crew and boat skipper) income (response variable). A number of predictor variables were considered, including level of schooling, fisher's age, fishing experience, length of the boat, number of crew for each fishing trip, the engine power of fishing boat, fishing gear and fishing effort (days per year). We used the subset regression approach with the leaps package to determine the best model executed from n-best models (one best model for each number of predictors) to nvmax (null in this case allows for no limit on number of variables) using an exhaustive approach. We chose the best model based on the adjusted $R^{2}$ and BIC values.

To assess the socioeconomic implications and ecological effectiveness of seasonal fishing bans, the interest of fishers toward involvement in decision-making and/or willingness to participate in resource management was assessed using Likert scale (Likert, 1932) responses. The use of Likert scales allowed respondents to share their thoughts (whether they agree or accept an opinion) on a 5 -point scale from 1 (= strongly disagree) to 5 (= strongly agree), with 3 being a neutral feeling or category. To do this, we used a questionnaire to assess the fishers' responses on three perceptions relevant to their socioeconomic condition (broadly illustrating the negative consequences of ban), which includes the negative impact on income, food security, and prevalence of conflicts. In addition, the ecological outcomes (potential positive consequences) of the bans were assessed in the form of fishers' perceptions regarding improvement in fish stocks, improvement in fish size, increased catch and better juvenile protection. Fishers' perception regarding existing resource management practices (positive role of management practice) was also explored in terms of their active involvement with the management body, the effectiveness of the current level of enforcement, up-to-date fisheries regulations and overall satisfaction with different management practices applied to small-scale marine fisheries. These answers for the different perceptions of socioeconomic conditions, ecological outcomes, and resource management were pooled and then averaged to create a single composite score for each of these criteria. These composite scores were used as the predictor variables to execute generalized linear model using the logit link function, also known as a logistic regression model. The response variables were the perception of the fishing ban (whether the ban is good or bad) and fishers' willingness to comply (whether they are ready to comply with or not) with the imposed regulation.

We also performed a total of four independent samples (Welch's) $t$-test to explore whether there were any differences in opinion regarding existing resource management practices and socioeconomic conditions between fishers that did and did not receive support and fishers that did or did not have a conflict with management. Additionally, the correlation between fishers' socioeconomic conditions and their perceptions of the ban was analyzed to check whether there were any underpinning socioeconomic factors shaping their perceptions of the ban. 
For analysis of qualitative data, the inductive content analysis method was employed; themes were identified and classified into manageable categories of different variables to provide further explanations.

\section{RESULTS}

\section{Socioeconomic Characteristics of the Respondents in the Fisher Survey}

This section describes the socio-economic profile of the respondents for the fisher survey. Of the total respondents, the majority (97.5\%) work as crew members, and about $2.5 \%$ are boat owners or skippers. The average age is $38.09( \pm 9.44)$ years. Almost two-thirds (66.9\%) are illiterate, $27.34 \%$ have received a primary level education and only $5.67 \%$ received education at the secondary level. Fishing is the only occupation for almost all $(98.84 \%)$ of the respondents. In response to options available for secondary occupation, the respondents are almost equally divided. There is a large variation in average fishing years between the two groups, with crew showing 16.29 ( \pm 8.38$)$ years, while the skippers (majhi) have a mean experience of $21.80( \pm 9.37)$ years within the overall mean experience of $18.12( \pm 9.07)$ years across fishers. More than two-thirds (67.63\%) of fishers do not have membership in any association, and about $70 \%$ do not have access to bank credit. Only about 30\% of fishers have access to social indebtedness (dadon taken from mohajon-fishery entrepreneur or boat owner). About 57.55\% people reported receiving assistance from the government, although not at a satisfactory level, and aid is not received by $42.45 \%$ of the respondents in the study sites. The average boat size used is $45.41( \pm 15.36)$ meters in length, with an average power of 62.35 $( \pm 38.33)$ hp. The mean number of crew members for each operation is $14.10( \pm 4.5)$. Almost two-thirds of $(64.75 \%)$ use an Ilish net (gill net) solely for fishing, and $35.25 \%$ use various other types of nets. The monthly average income is (USD) 252.18 $( \pm 131.07$; see Table 2).

\section{Socioeconomic Implications}

The respondents perceived substantial negative consequences depending upon the fisher's socioeconomic status. Almost all fishers perceived loss of their income during the fishing ban. For example, one fisher from the FGD in Kuakata said, "We cannot go to sea during the hilsa fishing ban. Also, extreme weather and climatic events reduced our fishing days every year. Now this long fishing ban has left us squeezing our fishing days. How can a family be maintained without fishing income for such a long time?" The result shows significant variation in the monthly income of the two groups of fishers. Fishers who work as boat owners or skippers earn significantly more than crew members $(t=-2.73$, $P=0.007)$. Fishers' income was driven by different factors. Multiple linear regression analysis shows that the monthly income of crew members is significantly and positively associated with higher level of schooling (secondary education), age and a higher number of crew members in each fishing trip, while higher fishing boat engine power potentially leads to higher fuel costs, which negatively influence income level (Table 3). This means, for example, that fishers with better education (schooling up to 10 years) could expect an average increase of USD 199 per month in income compared to fishers with no education. However, the income of boat owners or skippers was solely driven by their years of fishing experience (Table 4).

The FGD revealed that higher earnings from an increased fish catch do not increase crews' income much. A fisher from Fishery Ghat, Cox's Bazar stated, "Our monthly wage is fixed, and we benefited a little with a nominal incentive even if the

TABLE 2 | Socioeconomic profile of the respondents in the fishers' survey.

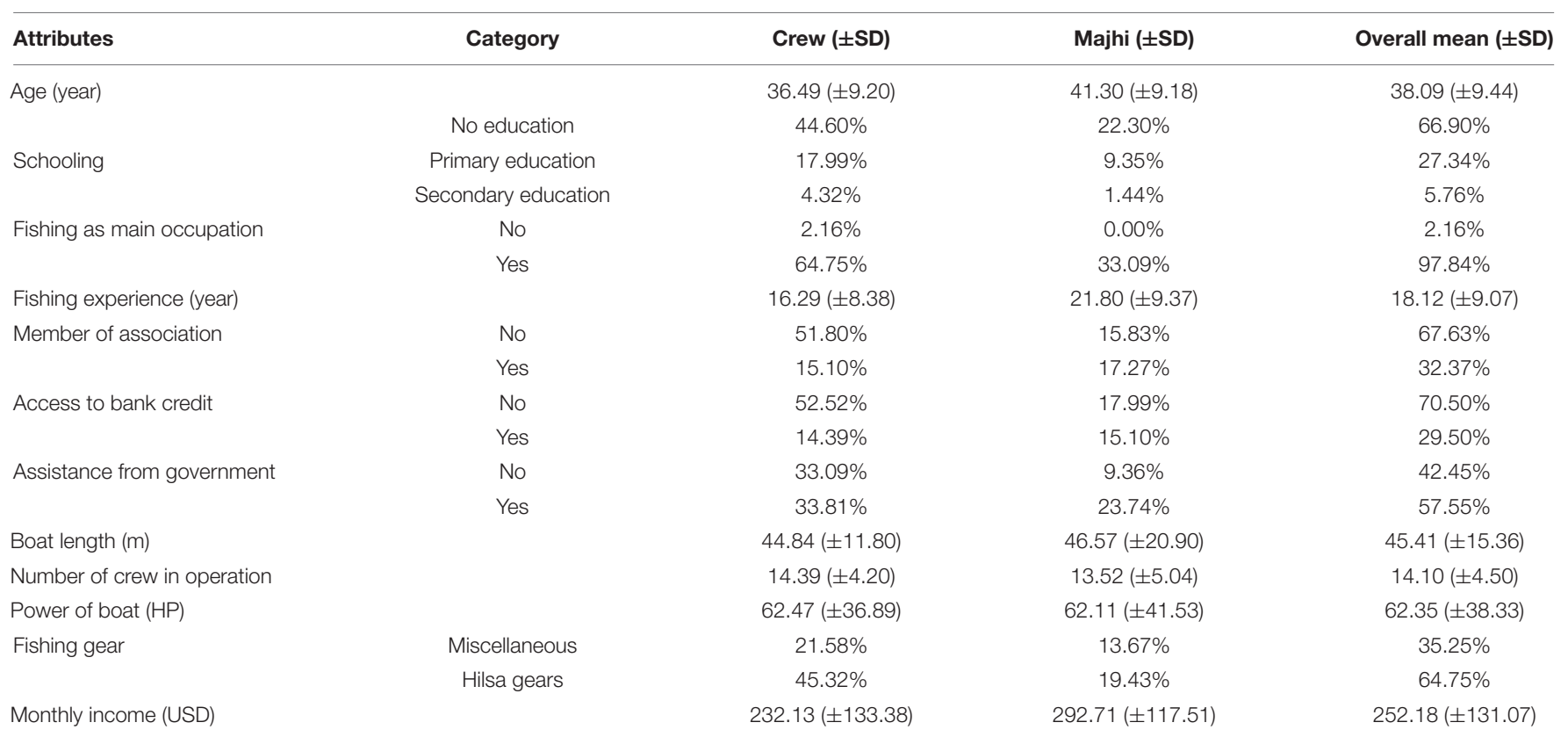


TABLE 3 | Determinants that affect the income of fishermen who work as crew in hilsa fisheries, as obtained from the fishers' survey.

\begin{tabular}{|c|c|c|c|c|}
\hline & Estimate & Std. error & $t$ value & $\operatorname{Pr}(>|t|)$ \\
\hline (Intercept) & -101.22 & 64.53 & -1.57 & 0.120 \\
\hline Age & 5.42 & 1.39 & 3.91 & $0.000^{\star \star \star}$ \\
\hline Schooling up to 5 years & 32.09 & 28.24 & 1.14 & 0.259 \\
\hline Schooling up to 10 years & 199.72 & 49.55 & 4.03 & $0.000^{\star \star \star}$ \\
\hline No of crew in the fishing trip & 12.60 & 3.32 & 3.79 & $0.000^{\star \star \star}$ \\
\hline Power of boat & -1.08 & 0.38 & -2.87 & $0.005^{\star \star}$ \\
\hline
\end{tabular}

Adjusted $R^{2}$ : 0.31, BIC: -16, F-statistic: 9.286, and DF: 87, p-value: 4.095e-07. Signif. codes: 0 " $* * * * 0.001$ "***”.

TABLE 4 | Determinants that affect the income of fishermen who work as skippers or boat owners in hilsa fisheries, as derived from the fishers' survey.

\begin{tabular}{lrrrl}
\hline & Estimate & Std. error & $\boldsymbol{t}$ value & $\operatorname{Pr}(>|\mathbf{t}|)$ \\
\hline (Intercept) & 125.26 & 36.31 & 3.45 & $0.001^{\text {** }}$ \\
Hilsa fishing gear only & 34.27 & 29.51 & 1.16 & 0.253 \\
Experience of fishing (year) & 5.89 & 1.71 & 3.45 & $0.001^{\text {** }}$ \\
Power of boat & 0.57 & 0.38 & 1.49 & 0.143 \\
Schooling as primary education & -53.66 & 29.01 & -1.85 & 0.072 \\
Schooling as secondary education & -27.54 & 65.12 & -0.42 & 0.675 \\
\hline
\end{tabular}

Adjusted $R^{2}$ : 0.49, BIC: -19, F-statistic: 9.485, and DF: 40, p-value: 5.049e-06. Signif. codes: 0.001 "***".

catches increase. However, when there is no catch or a poor catch, our wage is not fully paid, and we were affected the worst." The respondent fishers reported several socioeconomic implications of the fishing ban. The majority of the fishers lost income due to their lack of other work skills and/or due to the scarcity of alternative livelihood options. Some fishers reported migrating to another location in search of gainful occupation or to fish illegally. Most of the fishers said that their family suffered from food insecurity and occasional hunger during the ban period. Among the respondents in the fisher survey, about $29 \%$ of the households suffered from moderate hunger, and the majority of families (47\%) experienced occasional food insecurity.

More than half $(52 \%)$ of the respondents do not have a "jele card" (fisher identification card), which is a pre-condition for getting incentives from the government during the ban period. Only $43 \%$ of the respondents said they receive government support (rice) during the ban period. A key informant from Patharghata observed, "The number of unregistered fishermen is at least several times more than the registered ones." Fishers expressed disappointment on the rice scheme compensation. A fisher from Mohipur stated, "One cannot run a family only with a sack of rice; they need other means for living. Even the rice is not adequate in amount and improperly distributed." Another fisher from Kuakata said, "Fishing is the only occupation that I can do. There is no income source left in this ban period. How can a family of 9-10 members survive - I am worried." Another fisher from Mohipur said, "We laborers were hit hard, as we have only a small amount of savings, so I will not be able to run my household for the next 2 months. This is injustice for us." One key informant from Mohipur said, "Those fishers who do hilsa fishing were hit the hardest. Because they had to face two other ban fishing periods, along with this 65-day fishing ban. Again, fishers often have to return shore during extreme weather conditions. The consecutive bans and frequent bad weather conditions leave hardly enough time for fishing."

Of the total respondents in the fisher survey, 52\% managed to find seasonal, temporary employment, while a significant number (48\%) remain unemployed. Sudden prolonged restrictions on fishing put them in a debt trap. They must take on debt in the form of a loan from middlemen in contract for future fish sales after the ban season. More than half of the respondents (56\%) of the fisher survey received loans/support from the NGOs at the household level. Most of these NGOs run microcredit programs, but a few other NGOs ran training programs, particularly on different sustainable livelihood options for women, and provided them with assets, such as sewing machines.

\section{Ecological Benefits}

In response to a set of questions regarding the perceived ecological outcomes of the fishing ban, almost half of the (45\%) respondents in the fisher survey thought that the seasonal monsoon ban would increase catch during post-ban periods (Table 5). One respondent from Fishery Ghat, Cox's Bazar said, "If there is no fishing, no doubt the stock of the fishery will increase. That will ultimately increase our catch from fishing." Those fishers who disputed this claim argued that non-compliance by some fishers and illegal fishing by neighboring countries are barriers to the performance of the ban. Unless the government can stop illegal fishing by fishing fleets of neighboring countries, the ban will have little success, and only add suffering to the local fishers, as another fisher from Fishery Ghat, Cox's Bazar, claimed. About $24 \%$ of the participants in the fishery survey also believed the size of the fish catch per unit gear would increase. Another fisher interviewed from Kuakata expressed optimism: "Most of the fish in the Bay of Bengal lay eggs during the early monsoon, and therefore, this ban, if properly enforced, will increase the catch." Fishers also hoped to get more adult fish because of the ban; $18 \%$ of the respondents in the fisher survey thought the fishing ban protecting juvenile fish resulted in more adult fish production after the ban. A key informant from Mohipur stated, "This ban duration is during the spawning time for various marine fish, thus, allowing safe spawning that would result in a higher catch during the post-ban period." Some fishers disputed the timing of the ban, however; for example, one fisher from the FGD in Patharghata said, "No fish are breeding during JuneJuly: most of the fish lay eggs from September to October. So, the

TABLE 5 | Perceptions of participants (survey) on ecological performance of seasonal monsoon fish ban (Multivariate frequency analysis).

\begin{tabular}{ll}
\hline Perception on ecological performance & $\begin{array}{l}\text { Frequency (\%) } \\
\text { multiples responses }\end{array}$ \\
\hline Increase catch & 45.00 \\
Size of catch increase & 24.00 \\
More adult fish & 18.00 \\
Protecting juvenile fish & 12.00
\end{tabular}


timing of the ban period is not appropriate." One key informant from Fishery Ghat, Cox's Bazar said, "If appropriately enforced, along with adequate compensation or alternative livelihoods, this ban could help replenish the depleted fish stock in the Bay of Bengal."

\section{Drivers of Ban Compliance}

Most of the fishers (79\%) expressed their willingness to comply with the ban, while others (18\%) were likely to refuse to comply, according to the fishers' survey (Figure 2). The results indicate that fishers' expressed willingness to comply with the ban was mostly driven by their perception of its positive ecological outcomes (Table 6). The ecological outcome is here determined by their perception regarding whether a ban could replenish the overfished fish stocks, the potential to reverse the decrease in catch and size and the ban's effectiveness in protecting adult and juvenile fish, allowing safe spawning. The fishers who were willing to comply with the ban hoped there would be a remarkable increase in fish production after the ban. An elderly key informant fisherman from North Nuniarchora, Cox's Bazar, observed, "There were plentiful fishery resources in the sea 3035 years ago. We used to go fishing and returned within 5-6 days with a good catch, but at present, our sons go for 15-20 days and even for a month, but a good catch is not guaranteed. If this ban can be implemented properly, the catch could return." Despite being willing to comply with the ban, some fishers break the rule due to severe livelihood crises. "I am a by-born fisher, have no skill for other activities, and here there is no scope for agricultural activities. I have to go fishing in the small rivers along the Bay of Bengal for survival, though risking the penalty of breaking the rules," stated one key informant fisher from Kuakata. A boat owner from Fishery Ghat who participated in the FGD in Cox's Bazar said, "The ban on artisanal fishing came on all of a sudden, before the season start. We invested a lot of money to make the necessary preparations for a fishing trip. The ban was a huge loss; some people defied the ban to compensate for their loss, at least in part."

\section{Attitudes Toward Management Approach}

The results indicate that whether fishers consider the fish ban a good or bad thing was primarily based on the resource management practices of the implementing authority (Table 7). Resource management practices represent the cumulative score of peoples' perceptions of the level of satisfaction with the management, enforcement effectiveness, rationalization of the laws and fishers' active involvement in management. Fishers' opinions about existing resource management practices and socioeconomic conditions varied depending on their opinion about the resource management authority. Fishers who did not support the local resource management authority were significantly negative in their opinion $(t=-6.59, P=0.00)$ about existing resource management practices compared to their counterparts. In contrast, fishers who expressed their belief in significant positive consequences of the ban on their socioeconomic status ( $t=7.17, P=0.00$ ) were supportive of the local resource management authority. Fishers who received support from the government during the ban period opined that their socioeconomic condition had improved $(t=1.98, P=0.05)$, but this did not necessarily change their opinion regarding resource management practices $(P=0.10)$; this suggests that fishers are more concerned about their rights/role/engagement in fishing ban management practices than having financial support from the government.

The findings from the FGDs revealed that there are conflicts entrenched around various issues causing discontent among coastal and industrial fishers related to fishing areas, with fishers blaming each other for unsustainable fishing practices and illegal fishing by foreign trawlers, as well as harsh attempts to implement the ban by law enforcement agencies and concerns about the credibility of the implementation due to insufficient logistical capacities among the enforcing agencies. The dissatisfaction with the process of selecting beneficiaries for the compensation scheme and the distrust between the local fishers and government officers exacerbate these conflicts

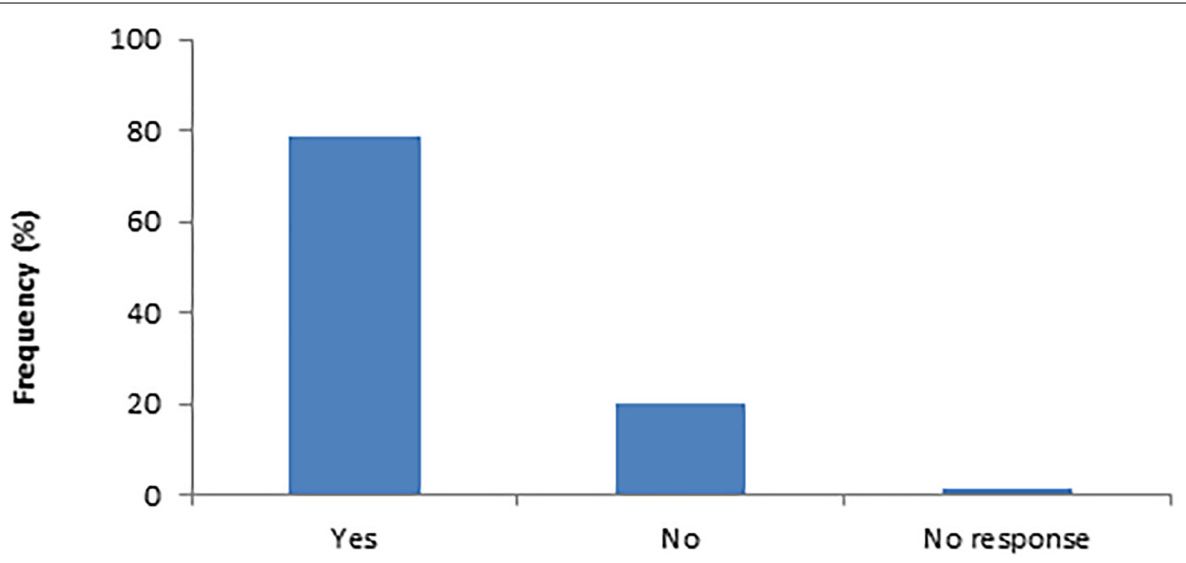

Fishers' perception regarding compliance with 65-days ban

FIGURE 2 | Perceptions of the surveyed fishers' of complying with the seasonal fishery closure. 
TABLE 6 | Results of generalized linear model shows factors that drives fisher's (engaged in hilsa fisheries) willingness to comply with fishing ban based on fishers' survey.

\begin{tabular}{|c|c|c|c|c|c|c|}
\hline & Estimate & Std. error & $z$ value & $\operatorname{Pr}(>|z|)$ & Cls $2.5 \%$ & Cls $97.5 \%$ \\
\hline (Intercept) & -2.172 & 3.006 & -0.722 & 0.470 & -8.05 & 3.85 \\
\hline Socioeconomic outcome & -0.464 & 0.522 & -0.889 & 0.374 & -1.55 & 0.51 \\
\hline Resource management & 0.619 & 0.334 & 1.850 & 0.064 & -0.02 & 1.30 \\
\hline Ecological outcome & 1.108 & 0.391 & 2.831 & 0.005 & 0.37 & 1.92 \\
\hline
\end{tabular}

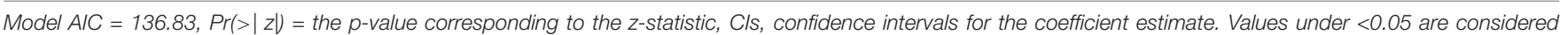
statistically significant and emphasized as bold.

TABLE 7 | Results of generalized linear model shows factors that influence fisher's (engaged in hilsa fisheries) decision on whether fishing ban good or bad based on fishers' survey.

\begin{tabular}{|c|c|c|c|c|c|c|}
\hline & Estimate & Std. error & $z$ value & $\operatorname{Pr}(>|z|)$ & Cls $2.5 \%$ & Cls $97.5 \%$ \\
\hline (Intercept) & 2.754 & 2.939 & 0.937 & 0.349 & -2.82 & 8.77 \\
\hline Socioeconomic condition & -0.959 & 0.543 & -1.768 & 0.077 & -2.09 & 0.05 \\
\hline Resource management & 0.703 & 0.323 & 2.177 & 0.030 & 0.09 & 1.36 \\
\hline Ecological outcome & 0.217 & 0.338 & 0.641 & 0.522 & -0.45 & 0.89 \\
\hline
\end{tabular}

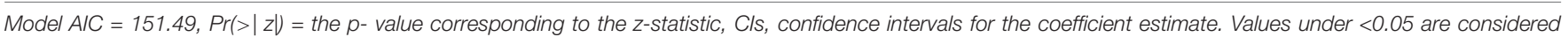
statistically significant and emphasized as bold.

(Table 8). Although many fishers are members of the local fishers' organization, they have little or no chance to participate in management decisions and implementation. Some fishers reported that, although cooperative society office holders were invited to join an informational meeting with officials from the Department of Fisheries related to government decisions, they had no opportunity to share their opinions. Fishers also expressed their concern regarding the effectiveness of the ban. The majority of the fishers claimed control of illegal fishing by neighboring countries in Bangladesh waters was limited or non-existent, and this became more prevalent during the ban. Some also expressed concern regarding enforcement inequality. One fisherman from Mohipur stated, "The rich fishermen do illegal fishing, and do not comply with laws, as they have enough money to bribe the officials." Another fisher from Patharghata said, "If the current jal (monofilament gill nets) and trawl fishing can be controlled, the fisheries will return to their previous state within shortest possible time periods." The FGD findings indicated that the distribution of the compensation scheme was highly politicized and marked by corruption. The FGDs also revealed several suggestions to improve management of the fishery, including participatory decision-making for the duration and exact period of fish spawning and closed season; a transparent, inclusive, and sufficient compensation scheme (both cash and food) for all affected fishers; an effective ban on trawling and use monofilament gill nets; capacity building among fishing households for alternative occupation; and effective enforcement against illegal fishing by foreign trawlers.

\section{Fishers' Response Strategies}

During the fishing ban, coastal fishers adopted different livelihood strategies to cope with the resulting economic crisis (Table 9). Most of the respondents reported negative coping strategies. To buy food and meet daily expenses, they drew from their savings, took loans from commission agents (fish traders) or boat owners, took an interest-free loan from relatives or microcredit from NGOs. In case of failure to receive a loan, fishers reported reducing the number of family meals per day or taking low-quality food. Among the participants in the fisher survey, about a quarter (25.68\%) of fishers had taken out a loan from a boat owner or money-lending relatives, or microcredit from NGOs. Approximately $20.27 \%$ of fishers stated that they had reduced their food consumption, while $2.70 \%$ took in lower

TABLE 8 | T-test results show whether there is any difference in the opinion regarding existing resource management practice and socioeconomic condition between fishers those received support or not and having conflict with management or not based on fishers' survey.

\begin{tabular}{lcccc}
\hline & & $\boldsymbol{t}$ & $\mathbf{d f}$ & $\boldsymbol{p}$-value \\
\hline \multirow{3}{*}{ Conflicts with management } & Resource management & -6.5889 & 138 & 0.000 \\
& Socioeconomic condition & 7.163 & 119 & 0.000 \\
Support & Resource management & 1.6472 & 144 & 0.102 \\
& Socioeconomic condition & 1.9772 & 139 & 0.050 \\
\hline
\end{tabular}

TABLE 9 | Coping strategies during the ban season by the participants in fisher survey.

\begin{tabular}{ll}
\hline Coping strategies & $\begin{array}{l}\text { Frequency } \\
\text { (\%) multiple } \\
\text { responses }\end{array}$ \\
\hline Income adjustment through loan & 25.68 \\
Food consumption adjustment & 20.27 \\
Alternative occupation & 13.51 \\
Liquidation of assets & 12.84 \\
Employing other family members into an occupation (e.g., child & 11.49 \\
labor) & \\
Expense from saving & 10.81 \\
Take low quality food & 2.70
\end{tabular}


quality foods to get the lowest price. One fisher from Mohipur stated, "We have a meal twice instead of thrice a day. Even during the ban, we have to take food with few vegetables and salt only." One key informant from Kuakata said, "Women and children are the worst affected by seasonal food insecurity, as usually earning member of the family get priority in food consumption." Only $13.51 \%$ of fishers adopted alternative occupations such as rickshaw pulling and payday labor to earn their livelihood. Another $12.84 \%$ of fishers reported that they had to sell assets to supports their families. Some fishers (about 11.49\%) involved their children in labor to support the family, while $10.81 \%$ spent their savings to cope with the lack of income. One key informant from Fishery Ghat, Cox's Bazar said, "Most of the coastal fishers have a marginal livelihood and live from hand to mouth without any savings." The fishers also took up strategies that put pressure on the fishery resources. Respondents reported that illegal fishing during the banned period or using destructive fishing gears were also prevalent.

\section{DISCUSSION}

The government of Bangladesh has been enforcing a 65-day long seasonal ban on all types of marine fishing to preserve the fish stock and to ensure ample populations of adult fish and crustacean species by boosting their breeding in the northern Bay of Bengal. Nevertheless, the closed season has created severe economic hardships, given the lack of sufficient alternative employment opportunities and the poor income distributions among the marginalized fishers/laborers. Consequently, the ban most affected the dependent fisher community, and this was reflected by several street protests by fishers in coastal districts, because the unprecedented ban on small-scale fishing but fishers into more vulnerable conditions than ever before.

Among the fishers, the income distinction between boat skippers and the crews of fishing boats is immediately noticeable. The position of fishers in boat staff determine their wages and income. The fishers who works as majhi (mostly the boat owner or most experienced fisher) has a higher income than the fisher who works as a crew member. Although the regulation has less impact on boat owners' socioeconomic security, it adversely affects the fishing crews employed (Colwell and Axelrod, 2017). There are various socioeconomic factors, such as age, education and number of fishers on the crew, that were found to affect the income of fishing crews. This suggests that, without the presence of any buffer (e.g., savings), crew fishers generally endure economic hardship and fishery closure placed severe strains on income, food security, health and the education of children in the fishing communities (Islam et al., 2018; Brillo et al., 2019). Consequently, the marginal small-scale fishers expressed deep concern about and protested against the ban for several days. The fishers think that the ban on small-scale fishing is an injustice and profoundly unfair (e.g., Bavinck et al., 2008), as the costs of conservation disproportionately fell on the marginal fishers (Islam, 2021).

The government compensation scheme, although it proved to be supportive, was not sufficient to meet the needs of the fishers' households. The experiences from the compensation scheme for the hilsa shad fishing bans in Bangladesh waters suggest that the scheme is insufficient, non-inclusive and poorly administered (Bladon et al., 2018; Islam, 2021). Strong opposition was demonstrated toward the mismanagement of the incentive scheme. Approximately half of affected fishers were included on the list, and some non-fishers were enlisted owing to their power and socio-political connections (Bladon et al., 2018). This likely increased dissatisfaction among fishers. The decisions related to the ban were often taken while keeping fishers in the dark and without any dialogue with the affects fishers and their organizations, which also raised the question of legitimacy. These negative feelings could hinder the management of fishery resources (Pezzuto et al., 2008), which, in turn, could present a challenge to the effectiveness of the conservation efforts (Islam, 2021). The exclusion of fishers from the decision-making process in management of local fisheries could drive fishers to noncompliance with the imposed regulation, thus interfering with stock maintenance (Musiello-Fernandes et al., 2017).

According to Cinner et al. (2006), the success of seasonal closures depends on low human population density, low fishing dependency and associated high ability for livelihood diversification, as well as the community having exclusive tenure over the resources. Communities in which dependence on marine resources is higher and there are fewer available livelihood options, periodic or permanent closures covering large proportions of the fishing areas may create significant economic disadvantages and may therefore be met with resistance. As the present findings indicate, small-scale fishers have lower literacy rates than the national average. Fishing skills, in combination with these low levels of education, cannot be readily converted to other skilled occupations. Again, it is difficult to find temporary employment during the portions of the year when the different bans occur, as most gainful occupations tend to demand a longterm commitment. The majority of the fishing villages are also in remote locations, far from economic centers. All of these factors make it difficult for fishers to obtain alternative employment during seasonal closures (Islam et al., 2018), which means they are left with no other choice but to take in the full impact of income loss during the imposed fishing ban (Brillo et al., 2019). This economic reason leads to the non-compliance evident in other areas implementing a closed season strategy (Colwell et al., 2019; Napata et al., 2020).

Nevertheless, most fishers have shown fairly positive conservationist views and possess constructive attitudes toward conservation strategies to sustain the resources of marine fisheries. The willingness to comply with a lengthy ban is contrary to their survival, however, as they are entirely dependent on fishery resources as their only means of livelihood. There are cases where a seasonal fishery closure has been successfully implemented because of its acceptance by the fishing communities (Colwell et al., 2017). Successful fishery management has several advantages, including improved planning, conflict management and ready acceptance of management decisions involving stakeholders (Sampedro et al., 2017; Lorenzen and Camp, 2019). To this end, ensuring equity is necessary for a sustainable fishery management approach, 
regardless of population growth, the number of fishers and other challenges (Finkbeiner et al., 2017). Ensuring distributional and procedural equity can lead to legitimacy, social justice, empowerment, better acceptance of management decisions, and enhanced compliance with regulations (Sutinen and Kuperan, 1999). Fishers' participation in management processes could also reduce the government's enforcement costs. If fishers and other actors are to shoulder responsibility for making decisions and managing sanctuaries, they are less likely to violate the regulations and may be more likely to foster accountable attitudes toward conservation (Mascia et al., 2010; Islam et al., 2016; UN Environment, 2019). Thus, ensuring procedural equity (i.e., the inclusive and effective participation of all stakeholders) in rule- and decision-making processes is essential.

Like other developing countries, Bangladesh lacks sufficient scientific data to pinpoint the ideal time span for closed seasons. In this situation, local ecological knowledge can help to develop management plans for local fisheries (Berkes and Turner, 2006; da Costa Oliveira et al., 2016). This arrangement is likely to promote a sense of shared responsibility between the management team and fishing communities. Local fishers are also likely to have this indigenous ecological knowledge about the breeding and nursery sites of fishing resources, which may help guide the choice of no-take areas or redefine their boundaries, thus increasing their legitimacy (Scholz et al., 2004). Conservation planning approaches that aim for distributional equity and other related elements are more likely to have a greater chance of being well received by stakeholders and achieving long-term conservation success (Kockel et al., 2020). Procedural legitimacy (concerning an open, transparent and inclusive decision-making process via the effective participation of all relevant stakeholders) is closely linked to perceptions of fairness (Sutinen and Kuperan, 1999; Loring, 2017; Zafra-Calvo et al., 2019). Unfortunately, no such legitimacy is currently evident in the present fishery closure strategy.

Involving fishers in decision-making, power sharing and encouraging them to take responsibility to liaise between the government and the communities through fishery co-management would enhance the effectiveness of local management initiatives (Jentoft, 2000). The underlying social and economic status of the fisher communities should be thoroughly studied prior to any management implementation. Measures should be properly addressed for the restoration of these resources, because the social impacts influence their success (Islam et al., 2017). The scarcity of livelihoods should be understood by prior consultation with fishers, and proper actions should be taken by providing input for appropriate additional livelihood opportunities (Amali Infantina et al., 2020). Food security issues are a major concern during the ban period. Ensuring basic needs are met is the first step in building an environment where new regulations may be negotiated, supported and successfully implemented (Colwell et al., 2019). Communities should be fully engaged in the planning and the maintenance, following their rights, practices, expectations, interests, expertise, capacities, and institutions (Howard et al., 2017). Provision should be made for a fair share of the gains of the intervention, and communities should not bear disproportionate costs (CBD, 2010). This highlights the importance of considering three elements of equity: recognition (who is acknowledged/included and how), procedure (decisionmaking process), and distribution (of benefits and burden) in any conservation initiatives (Campbell and Gray, 2019; Zafra-Calvo et al., 2019; Bennett et al., 2020).

Fishery managers and policymakers must exercise caution when relying solely on seasonal closure to address overexploitation and resource degradation. Fishing closure during the spawning season does not always lead to an increase in catches or a better recovery of stocks, particularly in multispecies fisheries, and it may only have a minimal effect on production if the overall annual active fishing effort remains constant (Arendse et al., 2007; Clarke et al., 2015). This is because the higher fishing effort is often associated with increased fishing mortality, which undermines the individual's, reproductive capacity despite the closed fishing season. Thus, an effective closed season would require implementing it in a way that the fishing effort would not only be redistributed outside the spawning season but would also be reduced overall.

Because the Bay of Bengal fishery is open access or weakly regulated, it is also susceptible to the "race to fish" particularly when the seasonal fishing closure is lifted, as fishers expect more fish following the ban periods. This tendency to harvest more is a serious problem, because it often persists even when there were similar or low CPUEs (Catch-per-unit efforts) before closure, and there are few incentive systems in place to encourage restraint (Murawski et al., 2005; Cohen et al., 2013; Birkenbach et al., 2017). Thus, seasonal closures cannot be effective on their own, when fishery closure is used in isolation (Cinner et al., 2006; Cohen et al., 2013; Napata et al., 2020). As such, this strategy should be implemented simultaneously with other tools, such as the establishment of Marine Protected Areas and gear restrictions, that would reduce fishing mortality even after the closure (Napata et al., 2020). There is evidence that fishers' profits could increase when fishery closures and gear restrictions are implemented together, regardless of increased fishing intensity, diverse gear and catch, poverty and unregulated markets (McClanahan, 2010).

Fisher cooperation is also crucial to the successful execution of the closed season (Bavinck et al., 2008). A comprehensive fishery management strategy to curb overfishing and additional local drivers that reflect the knowledge, culture, needs and beliefs of local stakeholders must be assessed and measured along with stock assessments and administrative decisions (Finkbeiner et al., 2017). This requires extensive cooperation between governmental and non-governmental parties to be truly effective. The present study also highlights the importance of addressing the social justice issues associated with resource management and suggests that successful bans depend on a close collaboration between government and local fishers' organizations, as well as a common understanding that the ban's necessity is imperative (Bavinck et al., 2008). Fishers' support, coupled with local ecological knowledge, increases the likelihood of achieving fishery and conservation targets more efficiently. By incorporating fishers into an ecosystem-based management approach, closures can help address the needs of 
global marine protection goals, as well as fishery production (Barley Kincaid and Rose, 2014). Finally, we argue for equity as a prerequisite to sustainability (Finkbeiner et al., 2017). Social equity would support fishers' access to the process of decisionmaking and rule-making procedures. Social equity also entails fair distribution of benefits and liabilities and would ensure social justice to affected fishing communities, boost legitimacy, support for management measures and improve compliance (Islam, 2021).

\section{CONCLUSION}

The seasonal fishery closure in the Bay of Bengal was implemented to ensure a safe environment for brood fish to breed and for their conservation, including recruits. While it may be premature to conclude that the closed season has resulted in a positive ecological outcome without any impact assessment, fishers' perceptions and the global literature suggest a positive role for such closed seasons on stock revitalization. The stakeholders did not ignore the potential positive functions of the closed season in improving the fishery stock; however, the negative externality is evident by the loss of income and employment during the ban period. Fishing crews were the most affected, due to their overreliance on the fishery and their lack of alternative skills and occupations. They particularly suffered because the decision was made without their participation and consultation. This situation raises questions of social equity and environmental injustice, which likely compromise the effectiveness and legitimacy of the conservation efforts. Consideration of the fishers' socioeconomic needs is essential, because they cannot forfeit their livelihoods and food security needs as they live on the margins of subsistence. This ethical and social ramification highlights the necessity of understanding the interconnectedness between fishers' socioeconomic conditions and ecological conservation needs (Islam et al., 2018). Adaptive management with local communities' participation could be rewarding in reducing livelihood hardships and enhancing positive ecological outcomes. In this arrangement, capacity building of local users in the form of appropriate inputs (e.g., various social welfare and local-level community development programs) and skill-building programs aimed at creating economic opportunities for fishing households should be a top priority. Policymakers, managers, academics, and research

\section{REFERENCES}

Allen, S. D., and Gough, A. (2006). Monitoring environmental justice impacts: vietnamese-American longline fishermen adapt to the Hawaii swordfish fishery closure. Hum. Organ. 65, 319-328. doi: 10.17730/humo.65.3. bcpx6u86wc6p8dtp

Amali Infantina, J., Priya, P., Deepak Samuel, V. K., Abhilash, K. R., Purvaja, R., and Ramesh, R. (2020). Sustainability at a cost: an inceptive analysis of "extended" fishing ban on the livelihoods of fishers of Tamil Nadu. Fish. Manage. Ecol. 27, 336-344. doi: 10.1111/fme.12416

Arendse, C. J., Govender, A., and Branch, G. M. (2007). Are closed fishing seasons an effective means of increasing reproductive output?. A per-recruit simulation using the limpet Cymbula granatina as institutions must review the current fishing ban policies and perform more detailed investigations on the impact of seasonal fishery closures, investigations that consider greater biological and socioeconomic factors.

\section{DATA AVAILABILITY STATEMENT}

The raw data supporting the conclusions of this article will be made available by the authors, without undue reservation.

\section{ETHICS STATEMENT}

Ethical review and approval was not required for the study on human participants in accordance with the local legislation and institutional requirements. Written informed consent for participation was not required for this study in accordance with the national legislation and the institutional requirements.

\section{AUTHOR CONTRIBUTIONS}

MMI was responsible for conceptualization, writing several sections, and editing the entire manuscript. AB collected the data and wrote several sections. HU analyzed the data, contributed to writing the result sections, and editing the manuscript. SMAR contributed to the more detailed analysis of qualitative data and to the editing of the revised manuscript. MMI, AB, SMAR, and HU read and approved the final version. All authors contributed to the article and approved the submitted version.

\section{ACKNOWLEDGMENTS}

We acknowledge the respondents of this study. Our sincere thanks to the reviewers for their helpful comments to improve the manuscript.

\section{SUPPLEMENTARY MATERIAL}

The Supplementary Material for this article can be found online at: https://www.frontiersin.org/articles/10.3389/fmars. 2021.704056/full\#supplementary-material

a case history. Fish. Res. 85, 93-100. doi: 10.1016/j.fishres.2007. 01.001

Arias, A., Cinner, J. E., Jones, R. E., and Pressey, R. L. (2015). Levels and drivers of fishers' compliance with marine protected areas. Ecol. Soc. 20:19.

Aswathy, N., Shanmugam, T. R., and Sathiadhas, R. (2011). Economic viability of mechanized fishing units and socio-economics of fishing ban in Kerala. Indian J. Fish. 58, 115-120. doi: 10.18551/rjoas.2020-05.12

Barley Kincaid, K., and Rose, G. A. (2014). Why fishers want a closed area in their fishing grounds: exploring perceptions and attitudes to sustainable fisheries and conservation 10 years post closure in Labrador, Canada. Mar. Policy 46, 84-90. doi: 10.1016/j.marpol.2014.01.007

Bavinck, M., De Klerk, L., Van Dijk, D., Rothuizen, J. V., Blok, A. N., Bokhorst, J. R., et al. (2008). Time-zoning for the safe-guarding of capture fisheries: a closed 
season in Tamil Nadu, India. Mar. Policy 32, 369-378. doi: 10.1016/j.marpol. 2007.08.007

Bennett, N. J., Calò, A., Di Franco, A., Niccolini, F., Marzo, D., Domina, I., et al. (2020). Social equity and marine protected areas: perceptions of small-scale fishermen in the Mediterranean Sea. Biol. Conserv. 244:108531. doi: 10.1016/ j.biocon.2020.108531

Berkes, F., and Turner, N. J. (2006). Knowledge, learning and the evolution of conservation practice for social-ecological system resilience. J. Hum. Ecol. 34, 479-494. doi: 10.1007/s10745-006-9008-2

Birkenbach, A. M., Kaczan, D. J., and Smith, M. D. (2017). Catch shares slow the race to fish. Nature 544, 223-226. doi: 10.1038/nature21728

Bladon, A. J., Mohammed, E. Y., Ali, L., and Milner-Gulland, E. J. (2018). Developing a frame of reference for fisheries management and conservation interventions. Fish. Res. 208, 296-308. doi: 10.1016/j.fishres.2018. 08.010

Brillo, B. B. C., Jalotjot, H. C., Cervantes, C. C., and Rola, A. C. (2019). Impact on income and livelihood of fisheries workers: closed fishing season policy for sardines in Zamboanga Peninsula, Philippines. J. Coast. Conserv. 23, 10571067. doi: 10.1007/s11852-019-00713-y

Campbell, L. M., and Gray, N. J. (2019). Area expansion versus effective and equitable management in international marine protected areas goals and targets. Mar. Policy 100, 192-199. doi: 10.1016/j.marpol.2018.11.030

Carvalho, P. G., Jupiter, S. D., Januchowski-Hartley, F. A., Goetze, J., Claudet, J., Weeks, R., et al. (2019). Optimized fishing through periodically harvested closures. J. Appl. Ecol. 56, 1927-1936. doi: 10.1111/1365-2664.13417

Catedrilla, L. C., Espectato, L. N., Serofia, G. D., and Jimenez, C. N. (2012). Fisheries law enforcement and compliance in District 1, Iloilo Province, Philippines. Ocean Coast. Manage. 60, 31-37. doi: 10.1016/j.ocecoaman.2012.01.003

CBD (2010). "Convention on Biological Diversity COP Decision X/2. Strategic Plan for Biodiversity 2011-2020. New York, NY: CBD.

Chimba, N., and Musuka, G. (2014). Impact of closed fishing season on the livelihood of fishers: a case of stratum I of Kafue fishery. J. Int. Life Sci. Res. $2,49-62$.

Cinner, J., Marnane, M. J., McClanahan, T. R., and Almany, G. R. (2006). Periodic closures as adaptive coral reef management in the Indo-Pacific. Ecol. Soc. 11:31.

Clarke, J., Bailey, D. M., and Wright, P. J. (2015). Evaluating the effectiveness of a seasonal spawning area closure. ICES J. Mar. Sci. 72, 2627-2637. doi: 10.1093/icesjms/fsv144

Central Marine Fisheries Research Institute [CMFRI]. (2007). CMFRI Newsletter No. 114 April-June 2007. 1-24.

Cohen, P. J., Cinner, J. E., and Foale, S. (2013). Fishing dynamics associated with periodically harvested marine closures. Glob. Environ. Change 23, 1702-1713. doi: 10.1016/j.gloenvcha.2013.08.010

Colwell, J. M. N., and Axelrod, M. (2017). Socio-economic impacts of a closed fishing season on resource-dependent stakeholders in Tamil Nadu, India: differences in income and expenditure effects by occupational group. Mar. Policy 77, 182-190. doi: 10.1016/j.marpol.2016.10.026

Colwell, J. M. N., Axelrod, M., and Roth, B. (2019). Unintended consequences of a seasonal ban on fishing effort in Tamil Nadu \& Puducherry, India. Fish. Res. 212, 72-80. doi: 10.1016/j.fishres.2018.12.003

Colwell, J. M. N., Axelrod, M., Salim, S. S., and Velvizhi, S. (2017). A gendered analysis of Fisherfolk's livelihood adaptation and coping responses in the face of a seasonal fishing ban in Tamil Nadu \& Puducherry, India. World Dev. 98, 325-337. doi: 10.1016/j.worlddev.2017.04.033

da Costa Oliveira, P., Di Beneditto, A. P. M., Bulhões, E. M. R., and Zappes, C. A. (2016). Artisanal fishery versus port activity in southern Brazil. Ocean Coast. Manage. 129, 49-57. doi: 10.1016/j.ocecoaman.2016.05.005

Delacre, M., Lakens, D., and Leys, C. (2017). Why Psychologists Should by Default Use Welch's t-test Instead of Student's t-test. Int. Rev. Soc. Psychol. 30, 92-101. doi: 10.5334/irsp.82

Finkbeiner, E. M., Bennett, N. J., Frawley, T. H., Mason, J. G., Briscoe, D. K., Brooks, C. M., et al. (2017). Reconstructing overfishing: moving beyond Malthus for effective and equitable solutions. Fish Fish. 18, 1180-1191. doi: 10.1111/faf. 12245

Fisheries Resource Survey System [FRSS] (2019). Fisheries Statistical Year Book of Bangladesh, 2017-2018. Dhaka: Ministry of Fisheries and Livestock, 52.

Hargraves, K. (2011). Why do We Have Closed Seasons? Available online at: http: //www.dpi.qld.gov.au/28_3055.htm. (accessed December 26, 2020).
Howard, J., McLeod, E., Thomas, S., Eastwood, E., Fox, M., Wenzel, L., et al. (2017). The potential to integrate blue carbon into MPA design and management. Aquat. Conserv. Mar. Freshw. Ecosyst. 27, 100-115. doi: 10.1002/aqc. 2809

Hussain, M. G., and Hoq, M. E. (eds) (2010). Sustainable Management of Fisheries Resources of the Bay of Bengal Support to Sustainable Management of the BOBLME Project. Mymensingh: Bangladesh Fisheries Research Institute.

Islam, M. M. (2021). Social dimensions in designing and managing marine protected areas in Bangladesh. Hum. Ecol. 49, 171-185. doi: 10.1007/s10745021-00218-z

Islam, M. M., Aktar, R., Nahiduzzaman, M., Barman, B. K., and Wahab, M. (2018). Social considerations of large river sanctuaries: a case study from the Hilsa shad fishery in Bangladesh. Sustainability 10:1254. doi: 10.3390/su10041254

Islam, M. M., Islam, N., Sunny, A. R., Jentoft, S., Ullah, M. H., and Sharifuzzaman, S. M. (2016). Fishers' perceptions of the performance of hilsa shad (Tenualosa ilisha) sanctuaries in Bangladesh. Ocean Coast. Manage. 130, 309-316. doi: 10.1016/j.ocecoaman.2016.07.003

Islam, M. M., Shamsuzzaman, M. M., Mozumder, M. M. H., Xiangmin, X., Ming, Y., and Jewel, M. A. S. (2017). Exploitation and conservation of coastal and marine fisheries in Bangladesh: Do the fishery laws matter? Mar. Policy 76, 143-151. doi: 10.1016/j.marpol.2016.11.026

Jentoft, S. (2000). The community: a missing link of fisheries management. Mar. Policy 24, 53-60. doi: 10.1016/s0308-597x(99)00009-3

Kincaid, K. B., and Rose, G. A. (2014). Why fishers want a closed area in their fishing grounds: exploring perceptions and attitudes to sustainable fisheries and conservation 10 years post closure in Labrador, Canada. Mar. Policy 46, 84-90.

Kockel, A., Ban, N. C., Costa, M., and Dearden, P. (2020). Evaluating approaches for scaling-up community-based marine-protected areas into socially equitable and ecologically representative networks. Conserv. Biol. 34, 137-147. doi: 10. 1111/cobi.13368

Kooiman, J., Jentoft, S., Bavinck, M., and Pullin, R. (2005). Fish for Life: Interactive Governance for Fisheries. (Amsterdam: Amsterdam University Press), 432.

Likert, R. (1932). A technique for the measurement of attitudes. Arch. Psychol. 140, $1-55$.

Lorenzen, K., and Camp, E. V. (2019). Density-dependence in the life history of fishes: When is a fish recruited? Fish. Res. 217, 5-10. doi: 10.1016/j.fishres.2018. 09.024

Loring, P. A. (2017). The political ecology of gear bans in two fisheries: Florida's net ban and Alaska's salmon wars. Fish Fish. 18, 94-104. doi: 10.1111/faf. 12169

Mascia, M. B., Claus, C. A., and Naidoo, R. (2010). Impacts of marine protected areas on fishing communities. Conserv. Biol. 24, 1424-1429. doi: 10.1111/j. 1523-1739.2010.01523.x

Maxwell, J. (1997). "Designing a qualitative study," in Handbook of Applied Social Research Methods, eds L. Bickman and D. J. Rog (New York, NY: Sage Publications, Inc), 69-100.

McClanahan, T. R. (2010). Effects of fisheries closures and gear restrictions on fishing income in a Kenyan Coral Reef. Conserv. Biol. 24, 1519-1528. doi: 10.1111/j.1523-1739.2010.01530.x

Momtaz, S., and Gladstone, W. (2008). Ban on commercial fishing in the estuarine waters of New South Wales, Australia: community consultation and social impacts. Environ. Impact Assess. Rev. 28, 214-225. doi: 10.1016/j.eiar.2007. 03.001

Morton, B. (2011). At last, a trawling ban for Hong Kong's inshore waters. Mar. Pollut. Bull. 6, 1153-1154. doi: 10.1016/j.marpolbul.2010.12.001

Murawski, S. A., Wigley, S. E., Fogarty, M. J., Rago, P. J., and Mountain, D. G. (2005). Effort distribution and catch patterns adjacent to temperate MPAs. ICES J. Mar. Sci. 62, 1150-1167. doi: 10.1016/j.icesjms.2005.04.005

Murshed-e-Jahan, K., Belton, B., and Viswanathan, K. K. (2014). Communication strategies for managing coastal fisheries conflicts in Bangladesh. Ocean Coast. Manage. 92, 65-73. doi: 10.1016/j.ocecoaman.2014.01.003

Musiello-Fernandes, J., Zappes, C. A., and Hostim-Silva, M. (2017). Small-scale shrimp fisheries on the Brazilian coast: stakeholders perceptions of the closed season and integrated management. Ocean Coast. Manage. 148, 89-96. doi: 10.1016/j.ocecoaman.2017.07.018

Napata, R. P., Espectato, L. N., and Serofia, G. D. (2020). Closed season policy in Visayan Sea, Philippines: a second look. Ocean Coast. Manage. 187, 105-115. 
Narayanakumar, R., Jayasankar, J., Shyam, S. S., Ganga, U., and Vivekanandan, E. (2017). Economic valuation of net social benefit of seasonal fishing ban in selected maritime states of India. Indian J. Fish. 64, 85-92.

Oliver, T. A., Oleson, K. L., Ratsimbazafy, H., Raberinary, D., Benbow, S., and Harris, A. (2015). Positive catch \& economic benefits of periodic octopus fishery closures: Do effective, narrowly targeted actions 'catalyze'broader management? PLoS One 10:e0129075. doi: 10.1371/journal.pone.0129075

Peterson, A. M., and Stead, S. M. (2011). Rule breaking and livelihood options in marine protected areas. Environ. Conserv. 38, 342-352. doi: 10.1017/ s0376892911000178

Pezzuto, P. R., Alvarez-Perez, J. A., and Wahrlich, R. (2008). The use of the swept area method for assessing the seabob shrimp Xiphopenaeus kroyeri (Heller, 1862) biomass and removal rates based on artisanal fishery-derived data in southern Brazil: using depletion models to reduce uncertainty. Lat. Am. J. Aquat. Res. 36, 245-257. doi: 10.3856/vol36-issue2-fulltext-7

Pita, C., Pierce, G. J., and Theodossiou, I. (2010). Stakeholders' participation in the fisheries management decision-making process: fishers' perceptions of participation. Mar. Policy 34, 1093-1102. doi: 10.1016/j.marpol.2010.03.009

Pranovi, F., Monti, M. A., Caccin, A., Brigolin, D., and Zucchetta, M. (2015). Permanent trawl fishery closures in the Mediterranean Sea: An effective management strategy? Mar. Policy 60, 272-279. doi: 10.1016/j.marpol.2015. 07.003

R Core Team (2020). R: A Language and Environment for Statistical Computing. Vienna: R Foundation for Statistical Computing.

Rahman, H. Z., Choudhury, L. A., and Wahab, M. A. (2014). Hilsa and Hilsa Fishermen: Exploring Conservation-Livelihood Win-Wins. Dhaka: Power and Participation Research Centre.

Rahman, M. A., Alam, M. A., Flura, A. T., Hasan, S. J., Ahmed, K. K. U., and Zaher, M. (2011). Hilsa Fisheries Research and Management. Extension Manual No 42. Mymensingh: Bangladesh Fisheries Research Institute.

Rola, A. C., Narvaez, T. A., Naguit, M. R. A., Elazegui, D. D., Brillo, B. B. C., Paunlagui, M. M., et al. (2018). Impact of the closed fishing season policy for sardines in Zamboanga Peninsula, Philippines. Mar. Policy 87, 40-50. doi: 10.1016/j.marpol.2017.09.029

Sampedro, P., Prellezo, R., García, D., Da-Rocha, J. M., Cerviño, S., Torralba, J., et al. (2017). To shape or to be shaped: engaging stakeholders in fishery management advice. ICES J. Mar. Sci. 74, 487-498. doi: 10.1093/icesjms/fsw160

Scholz, A., Bonzon, K., Fujita, R., Benjamin, N., Woodling, N., Black, P., et al. (2004). Participatory socioeconomic analysis: drawing on fishermen's knowledge for marine protected area planning in California. Mar. Policy 28, 335-349. doi: 10.1016/j.marpol.2003.09.003
Sherman, K. D., Shultz, A. D., Dahlgren, C. P., Thomas, C., Brooks, E., Brooks, A., et al. (2018). Contemporary and emerging fisheries in The BahamasConservation and management challenges, achievements and future directions. Fish. Manage. Ecol. 25, 319-331. doi: 10.1111/fme.12299

Shyam, S. S., Vijayan, H., and Sandhya, K. M. (2010). Trade-off between monsoon trawl ban and the livelihood of trawl labourers in Maharashtra. Indian J. Fish. $57,67-71$.

Sutinen, J. G., and Kuperan, K. (1999). A socio-economic theory of regulatory compliance. Int. J. Social Ecol. 26, 174-193. doi: 10.1108/03068299910229569

UN Environment (2019). Enabling Effective and Equitable Marine Protected Areas Guidance on Combining Governance Approaches. Nairobi: UN Environment.

van Brakel, M. L., Nahiduzzaman, M., Haque, A. M., Mustafa, M. G., Rahman, M. J., and Wahab, M. A. (2018). Reimagining large-scale open-water fisheries governance through adaptive comanagement in hilsa shad sanctuaries. Ecol. Soc. 23:26.

Vivekanandan, E., Narayanakumar, R., Najmudeen, T. M., Jayasankar, J., and Ramachandran, C. (2010). Marine fisheries policy brief-2; seasonal fishing ban. CMFRI Spec. Publ. 103, 1-44.

Yin, R. K. (2015). Qualitative Research from Start to Finish, 2nd Edn. The New York, NY: Guilford Press.

Zafra-Calvo, N., Garmendia, E., Pascual, U., Palomo, I., Gross-Camp, N., Brockington, D., et al. (2019). Progress toward equitably managed protected areas in Aichi target 11: a global survey. Bioscience 69, 191-197.

Conflict of Interest: The authors declare that the research was conducted in the absence of any commercial or financial relationships that could be construed as a potential conflict of interest.

Publisher's Note: All claims expressed in this article are solely those of the authors and do not necessarily represent those of their affiliated organizations, or those of the publisher, the editors and the reviewers. Any product that may be evaluated in this article, or claim that may be made by its manufacturer, is not guaranteed or endorsed by the publisher.

Copyright (c) 2021 Islam, Begum, Rahman and Ullah. This is an open-access article distributed under the terms of the Creative Commons Attribution License (CC BY). The use, distribution or reproduction in other forums is permitted, provided the original author(s) and the copyright owner(s) are credited and that the original publication in this journal is cited, in accordance with accepted academic practice. No use, distribution or reproduction is permitted which does not comply with these terms. 